\title{
Cloning, nucleotide sequence and characterization of the mannitol dehydrogenase gene from Rhodobacter sphaeroides
}

\author{
Karl-Heinz Schneider, ${ }^{1}$ Friedrich GiffHorn ${ }^{1}$ and Samuel Kaplan ${ }^{2 *}$ \\ ${ }^{1}$ Institut für Angewandte Mikrobiologie, Universität des Saarlandes, Im Stadtwald, 6600 Saarbrücken, Germany \\ ${ }^{2}$ Department of Microbiology and Molecular Genetics, The University of Texas, Health Science Center at Houston, \\ Houston, Texas 77225, USA
}

(Received 15 January 1993; revised 13 April 1993; accepted 5 May 1993)

\begin{abstract}
Transposon mutagenesis and antibiotic enrichment were employed to isolate a mutant of Rhodobacter sphaeroides Si4 designated strain M22, that had lost the ability to grow on D-mannitol and to produce the enzyme mannitol dehydrogenase (MDH). DNA flanking the transposon in the mutant strain was used as a probe for the identification and cloning of the MDH gene (mtlK). A $5.5 \mathrm{~kb} E c o \mathrm{RI} / B g I \mathrm{II}$ fragment from $R$. sphaeroides Si4 was isolated and shown to complement the mutation in $R$. sphaeroides M22. Successful complementation required that a promoter of the vector-plasmid pRK415 be present, suggesting that the mtlK gene is part of a larger operon. Using oligonucleotides derived from the $\mathrm{N}$-terminal sequence of $\mathrm{MDH}$ as probes $m t l K$ was located on the complementing fragment and the gene was sequenced. The $m t l K$ open reading frame encodes a protein of $51404 \mathrm{Da}$ with an N-terminal sequence identical to that obtained from amino acid analysis of the purified MDH. The MDH of $\boldsymbol{R}$. sphaeroides Si4 exhibits distant similarity to the mannitol-1-phosphate dehydrogenases from Escherichia coli and Enterococcus faecalis, with $28.1 \%$ and $26.3 \%$ identity, respectively. Mutant strains deficient in MtlK displayed substantial levels of sorbitol dehydrogenase activity, originally thought to be only a minor activity associated with the MDH enzyme. It is likely that we have uncovered an additional polyol dehydrogenase with activity for sorbitol. The $m t l K$ gene can be used for overexpression of MDH in $E$. coli in order to obtain sufficient amounts of enzyme for further investigations and applications.
\end{abstract}

\section{Introduction}

Several bacterial polyol dehydrogenases such as sorbitol dehydrogenase (Horwitz \& Kaplan, 1964; Schneider \& Giffhorn, 1991), mannitol dehydrogenase (Martinez et al., 1963; Schneider \& Giffhorn, 1989), ribitol dehydrogenase (Kahle et al., 1992; Taylor et al., 1974), and arabitol dehydrogenase (Neuberger et al., 1979) have been isolated and characterized. Currently the potential use of different microbial polyol dehydrogenases for enzymic polyol determinations is being studied (Berezenko \& Sturgeon, 1991; Kiba et al., 1991; Lunn et al., 1989; Schmolke et al., 1990; Schneider \& Giffhorn, 1989, 1991). The applicability of these enzymes to polyol analyses is limited for two reasons: most polyol

*Author for correspondence. Tel +1713794 1742; fax +1713794 1782; e-mail skaplan@utmmg.med.uth.tmc.edu.

Abbreviation: MDH, mannitol dehydrogenase.

The GenBank accession number for the nucleotide sequence data reported in this paper is $\mathrm{L} 13697$. dehydrogenases are not highly specific and convert more than one polyol (Kiba et al., 1991; Schneider \& Giffhorn, $1989,1991)$; and the $K_{\mathrm{m}}$ values are often higher than $10 \mathrm{~mm}$, which impedes complete turnover of the substrates (Berezenko \& Sturgeon, 1991). Besides screening for new polyol dehydrogenases, investigations pertaining to the fundamentals of substrate specificity and ways to alter specificity of these enzymes offer possibilities of obtaining more suitable enzymes for analytical purposes. For these investigations knowledge about the exact structure of the proteins and the mechanism of the catalysed reactions are necessary. Recently we reported the isolation and characterization of a mannitol dehydrogenase (MDH; EC 1.1.1.67) from Rhodobacter sphaeroides $\mathrm{Si} 4$ and its application to quantitative Dmannitol determination taking advantage of the unusually low $K_{\mathrm{m}}$ value for D-mannitol (Schneider \& Giffhorn, 1989). Because of its monomeric structure this enzyme is particularly suitable for further studies. These studies require that the gene for $\mathrm{MDH}$ be available and the primary structure of the enzyme be determined. Until now few investigations concerning the genes for bacterial 
Table 1. Bacterial strains and plasmids

\begin{tabular}{|c|c|c|}
\hline $\begin{array}{l}\text { Strain or } \\
\text { plasmid }\end{array}$ & Relevant characteristic(s) & $\begin{array}{l}\text { Reference or } \\
\text { source }\end{array}$ \\
\hline \multicolumn{3}{|l|}{ R. sphaeroides } \\
\hline $\mathrm{Si} 4$ & Wild-type & Rode \& Giffhorn (1983) \\
\hline M22 & Tn5 mutant of Si4, $\mathrm{Km}^{\mathrm{r}} \mathrm{Man}^{-}$ & This study \\
\hline \multicolumn{3}{|l|}{ E. coli } \\
\hline JM101 & thi-1 (lac proAB) $[\mathrm{F}$ traD36, pro $A B$, lacZM15] & Yanisch-Perron et al. (1985) \\
\hline JE85 & $\mathrm{Phe}^{-}$mutant of $E$. coli $\mathrm{DH} 5 \alpha$ & Jesus Eraso* \\
\hline S17-1 & $\begin{array}{l}\text { Pro }^{-} \operatorname{Res}^{-} \mathrm{Mod}^{+} \operatorname{rec} A \text {, integrated plasmid RP4-Tc::Mu- } \\
\mathrm{Km}:: \operatorname{Tn} 7\end{array}$ & Simon et al. (1983) \\
\hline HB101 & $\operatorname{Res}^{-} \operatorname{Mod}^{-} \operatorname{rec} A 13 \mathrm{Sm}^{\mathrm{r}}$ & $\begin{array}{l}\text { Boyer \& Roulland-Dussoix } \\
\text { (1969) }\end{array}$ \\
\hline \multicolumn{3}{|l|}{ Plasmid } \\
\hline pMH1701 & Suicide plasmid containing $\mathrm{Tn} 5-\mathrm{B} 12 \mathrm{~S}, \mathrm{Km}^{\mathrm{r}}$ & Hynes et al. (1989) \\
\hline pRK415 & IncP $\mathrm{Tc}^{\mathrm{r}} l a c Z \alpha m o b$ & Keen et al. (1988) \\
\hline pRK2013 & ColE1 replicon, $\mathrm{Tra}^{+}$of $\mathrm{RK} 2, \mathrm{Km}^{\mathrm{r}}$ & Ditta et al. (1980) \\
\hline pUC19 & Cloning vector, $\mathrm{Ap}^{\mathrm{r}}$ & Yanisch-Perron et al. (1985) \\
\hline pBS II KS $\mathrm{KS}^{+}$ & Cloning vector, $\mathrm{Ap}^{\mathrm{r}}$ & Stratagene \\
\hline pAK10 & $\begin{array}{l}\text { Parts of Tn5 with flanking DNA from } R . \text { sphaeroides M22 in } \\
\text { pUC19 }\end{array}$ & This study \\
\hline pAK20 & Eco RI/HindIII fragment of pAK10 in pUC19 & This study \\
\hline pAK30 & $\begin{array}{l}8 \mathrm{~kb} \text { DNA fragment from } R \text {. sphaeroides } \mathrm{Si} 4 \text { in } \mathrm{pRK} 415 \text { which } \\
\text { complements the mutation in } R \text {. sphaeroides } \mathrm{M} 22\end{array}$ & This study \\
\hline pAK36 & $5.5 \mathrm{~kb} E c o \mathrm{RI} / B g l \mathrm{II}$ fragment from pAK 30 in pRK 415 & This study \\
\hline pAK60 & $\begin{array}{l}5.5 \mathrm{~kb} E c o \mathrm{RI} / B g l \mathrm{II} \text { fragment from pAK } 30 \text { in pBluescript II } \\
\mathrm{KS}\end{array}$ & This study \\
\hline pAK63 & $\begin{array}{l}\text { As pAK60, but with the } E c o \mathrm{RI} / B g l \mathrm{II} \text { fragment in opposite } \\
\text { orientation }\end{array}$ & This study \\
\hline
\end{tabular}

* University of Texas Health Science Center at Houston.

polyol dehydrogenases have been performed. Only the ribitol dehydrogenase gene from Klebsiella pneumoniae has been sequenced (Loviny et al., 1985). The present communication reports the cloning and sequencing of the MDH gene $(m t l K)$ from Rhodobacter sphaeroides.

\section{Methods}

Bacterial strains and plasmids. These are described in Table 1.

Media. R. sphaeroides was grown chemoheterotrophically at $30^{\circ} \mathrm{C}$ in LB medium or in 'Sistrom minimal medium A' lacking glutamate and aspartate (Lueking et al., 1978) with either D-mannitol (Sis-mannitol medium) or D-fructose (Sis-fructose medium) or succinate (Sissuccinate medium) as sole carbon source. Escherichia coli was grown at $37^{\circ} \mathrm{C}$ in LB medium. When appropriate, antibiotics were added to the following concentrations: kanamycin $25 \mu \mathrm{g} \mathrm{ml}^{-1}$; spectinomycin $50 \mu \mathrm{g} \mathrm{ml}^{-1}$; streptomycin $50 \mu \mathrm{g} \mathrm{ml}^{-1}$; ampicillin $75 \mu \mathrm{g} \mathrm{ml}^{-1}$; tetracycline $1 \mu \mathrm{g} \mathrm{ml}^{-1}$ for $R$. sphaeroides and $10 \mu \mathrm{g} \mathrm{m}^{-1}$ for E. coli.

Genetic techniques. Plasmids were mobilized into $R$. sphaeroides by diparental mating with $E$. coli $\mathrm{S} 17.1$ or by triparental mating using $E$. coli HB101(pRK2013) as a helper as described by Suwanto \& Kaplan (1992). The matings were performed for $8 \mathrm{~h}$ at $30^{\circ} \mathrm{C}$ on LB plates.

DNA manipulations and Southern hybridizations. Chromosomal DNA from $R$. sphaeroides was isolated by the method of Marmur (1961); plasmid isolation from $E$. coli was performed by the method of Birnboim \& Doly (1979). Standard DNA techniques were used as described by Sambrook et al. (1989). DNA fragments were isolated from agarose gels using the Gene Clean Kit (Bio 101).
For Southern hybridizations with oligonucleotide probes, the oligonucleotides were labelled with [ $\alpha^{32}$ P]ATP (Amersham) using polynucleotide kinase from Pharmacia. The labelled oligonucleotides were purified by column chromatography on Nuctrap push columns from Stratagene. Hybridizations were performed for $12 \mathrm{~h}$ at $30^{\circ} \mathrm{C}$. The hybridization buffer contained: $50 \mathrm{mM}-\mathrm{Tris} / \mathrm{HCl}, \mathrm{pH} 7.5 ; 1 \%(\mathrm{w} / \mathrm{v})$ SDS; $1 \mathrm{M}-\mathrm{NaCl} ; 10 \%(\mathrm{w} / \mathrm{v})$ dextran sulphate; and $0.15 \mathrm{mg}$ salmon sperm DNA ml-1. After hybridization the membranes were washed twice at $40^{\circ} \mathrm{C}$ in $6 \times \mathrm{SSC}+1 \%(\mathrm{w} / \mathrm{v})$ SDS and subjected to autoradiography $(1 \times \mathrm{SSC}$ is $0.15 \mathrm{M}-\mathrm{NaCl}, 0.015 \mathrm{M}$-trisodium citrate). For hybridizations with DNA fragments, the fragments were labelled by biotinylation with the BioNick kit from BRL. After hybridizations had been performed at $60^{\circ} \mathrm{C}$ for $12 \mathrm{~h}$ in the same buffer as described above the membranes were washed twice at $60^{\circ} \mathrm{C}$ in $6 \times \mathrm{SSC}+$ $1 \%$ SDS. The biotinylated probes were detected using the Photogene system from BRL.

Transposon tagging of mtlK. Plasmid pMH1701 containing Tn5 was introduced into $R$. sphaeroides by diparental mating on a sterile filter that was placed on an LB plate (Suwanto \& Kaplan, 1992). After mating for $8 \mathrm{~h}$ at $30^{\circ} \mathrm{C}$ the cells were suspended in $10 \mathrm{ml}$ Sis-mannitol medium and incubated on a rotary shaker at $30^{\circ} \mathrm{C}$ for $8 \mathrm{~h}$. Subsequently $50 \mu \mathrm{g}$ cefsulodin $\mathrm{ml}^{-1}$ and $50 \mu \mathrm{g}$ methicillin $\mathrm{ml}^{-1}$ were added in order to enrich mutants that were unable to grow with D-mannitol. The combined mixture of these antibiotics effectively kills cells of $R$. sphaeroides growing either chemoheterotrophically or phototrophically, but does not kill cells that are not growing (M. D. Moore \& S. Kaplan, unpublished results). Because of the intrinsic resistance of $R$. sphaeroides to most natural and synthetic penicillins, the above procedure has proven extremely useful. The cell suspension was incubated with shaking for $12 \mathrm{~h}$. Cells were harvested, washed twice in Sis-mannitol medium, resuspended in $600 \mu \mathrm{l} \mathrm{Sis-mannitol} \mathrm{medium} \mathrm{and}$ 
plated on Sis-succinate plates supplemented with kanamycin and, in order to prevent growth of E. coli, with $10 \mu \mathrm{g} \mathrm{K}_{2} \mathrm{TeO}_{3} \mathrm{ml}^{-1}$ (Moore \& Kaplan, 1992). The plates were incubated at $30^{\circ} \mathrm{C}$. By replica plating of the grown colonies on Sis-fructose plates and Sis-mannitol plates presumptive mutants that were able to grow on D-fructose but not on D-mannitol were identified.

Enzyme assays and protein determination. Polyol dehydrogenase activities were determined as described previously (Schneider \& Giffhorn, 1989). Protein concentrations were measured by the method of Goa (1953). Crystalline bovine serum albumin was employed as standard.

Determination of the N-terminal amino acid sequence of $M D H$. The amino acid sequence of the $\mathrm{N}$-terminal region of the isolated $\mathrm{MDH}$ was determined by automated Edman degradation using the pulsed liquid phase protein sequencer $477 \mathrm{~A}$ with an on-line $120 \mathrm{~A} \mathrm{PTH}$ analyser (Applied Biosystems). The sequencing was performed by $\operatorname{Dr} B$. Schmidt, Biochemistry II, Universität Göttingen, Germany.

DNA sequencing. DNA was sequenced by the dideoxy chaintermination method of Sanger with double-stranded (plasmid) templates using the Bst-Polymerase 7-deaza-dGTP Sequencing Kit from BioRad and ${ }^{35}$ S-dATP (Amersham). A $5.5 \mathrm{~kb}$ DNA fragment containing $m t l K$ was cloned in both orientations into pBluescript II KS (Stratagene) and nested deletions were produced using the ExoIII/ Mung Bean Deletion Kit from Stratagene. The T7-primer was used for the sequencing reactions as well as synthetic oligonucleotides complementary to already sequenced regions on the template.

In addition the same templates and primers were used for automated sequencing with the Applied Biosystems 370A/373A apparatus in the DNA core faculty of the Department of Microbiology and Molecular Genetics, University of Texas Medical School, Houston.

\section{Results}

\section{Cloning of mtlK from $R$. sphaeroides Si4}

In order to clone the gene for $\mathrm{MDH}(\mathrm{mtlK})$ from $R$. sphaeroides Si4 we obtained partial amino acid sequence information for the enzyme and subsequently deduced the corresponding nucleotide sequences, which could be used to identify $m t l K$. Purification of MDH from $R$. sphaeroides was performed according to the protocol described previously (Schneider \& Giffhorn, 1989). The first 43 amino acids of the enzyme were determined by automated sequencing; the sequence is shown in Fig. $1(a)$. Four different oligonucleotides were synthesized, the nucleotide sequences of which were deduced from this amino acid sequence. The sequences of the oligonucleotides are shown in Fig. 1(b); all of them have several 'wobble' positions. Unfortunately, our attempts to identify $m t l K$ in a cosmid bank of genomic DNA from $R$. sphaeroides $\mathrm{Si} 4$ were not successful.

Therefore it was necessary to use a completely different strategy to clone $m t l K$. Thus, by producing a mutant of $R$. sphaeroides with a transposon inserted in or near $m t l K$, DNA flanking the transposon could be used as a homologous probe to identify the gene for $\mathrm{MDH}$ following suitable enrichment of the mutant organism.
Transposon-induced mutants of $R$. sphaeroides were produced and enriched as described in Methods. Subsequently mutants were selected that did not form colonies on minimal plates with D-mannitol as sole carbon source. These mutants were grown in Sissuccinate medium supplemented with $10 \%$ LB medium and $5 \mathrm{~g}$ D-mannitol $\mathrm{l}^{-1}$, crude extracts were produced using a French press, and the specific polyol dehydrogenase activities were determined. One of the mutants was able to utilize D-fructose and other sugars as sole carbon source, but neither D-mannitol nor D-arabitol. In the crude extract of this strain no polyol dehydrogenase activity with either D-mannitol or D-arabitol was detectable (Table 2). The mutant strain was designated $R$. sphaeroides M22.

(a)

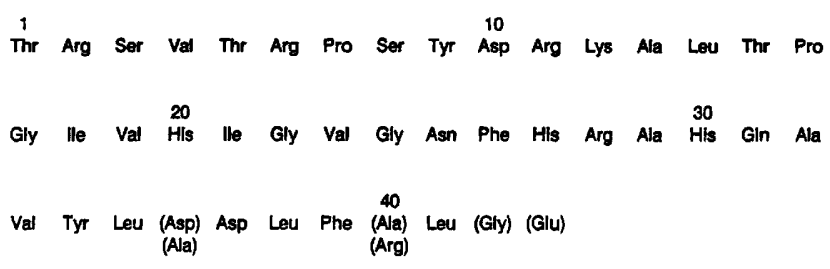

(b)

Oligonucleotide 1: 5'-ARNGCYTTNCKRTCRTA-3'

Ollgonucleotide 2: 5'-CCDATRTGNACDATNCC 3'

Oligonucleotide 3: 5'-CKRT GRAARTTNCCNAC 3'

Ollgonucleotide 4: 5'-ARRTANA CNG CYTGRTG-3'

Fig. 1. (a) Sequence of the $\mathrm{N}$-terminal portion of the MDH from $R$. sphaeroides Si4. Amino acids in parentheses indicate that a definite identification was not possible. (b) Sequences of the oligonucleotides, derived from the amino acid sequence of the $\mathrm{MDH}$, that were used as probes. $\mathrm{D}=\mathrm{G}+\mathrm{A}+\mathrm{T} ; \mathrm{K}=\mathrm{G}+\mathrm{T} ; \mathrm{N}=\mathrm{A}+\mathrm{C}+\mathrm{G}+\mathrm{T} ; \mathrm{R}=\mathrm{A}+\mathrm{G}$; $\mathrm{Y}=\mathrm{C}+\mathrm{T}$.

Table 2. Specific polyol dehydrogenase activities in crude extracts of $R$. sphaeroides strains Si4, M22, and M22 containing pAK30

The strains were grown in Sis-mineral medium which contained Dfructose as well as D-mannitol as carbon source. One unit (U) of enzyme activity was defined as the amount of enzyme required to reduce $1 \mu \mathrm{mol} \mathrm{NAD}^{+} \mathrm{min}^{-1}$ under standard assay conditions (Schneider \& Giffhorn, 1989). The margin of error for each measurement is $\pm 5 \%$.

\begin{tabular}{|c|c|c|c|}
\hline \multirow{2}{*}{$\begin{array}{l}\text { Polyol in } \\
\text { enzyme } \\
\text { assay }\end{array}$} & \multicolumn{3}{|c|}{$\begin{array}{l}\text { Specific activity } \\
{\left[\mathrm{U}(\mathrm{mg} \text { protein })^{-1}\right]}\end{array}$} \\
\hline & $\mathrm{Si} 4$ & M22 & $\mathrm{M} 22(\mathrm{pAK} 30)$ \\
\hline D-Mannitol & 0.09 & 0.00 & 0.19 \\
\hline D-Arabitol & $0 \cdot 20$ & 0.00 & 0.41 \\
\hline D-Glucitol & $0 \cdot 16$ & $0 \cdot 19$ & 0.63 \\
\hline Ribitol & 0.02 & 0.01 & 0.03 \\
\hline Xylitol & 0.01 & 0.01 & 0.04 \\
\hline
\end{tabular}


(a)

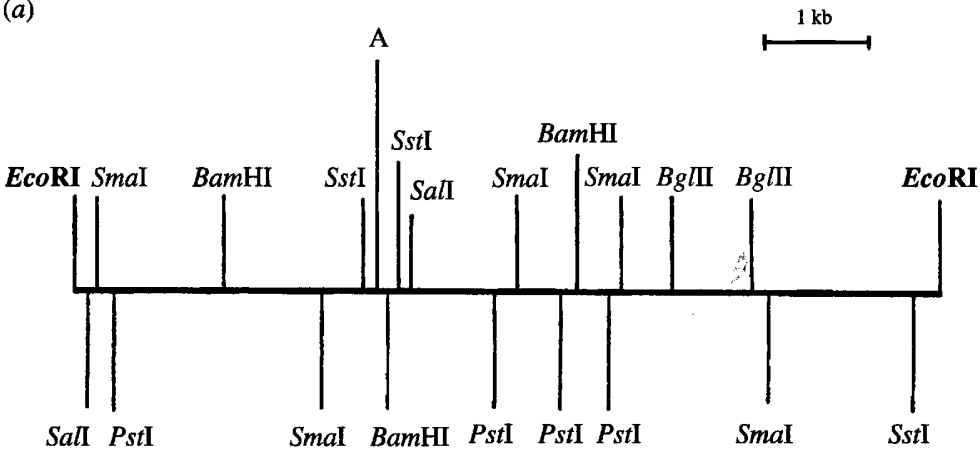

(b)
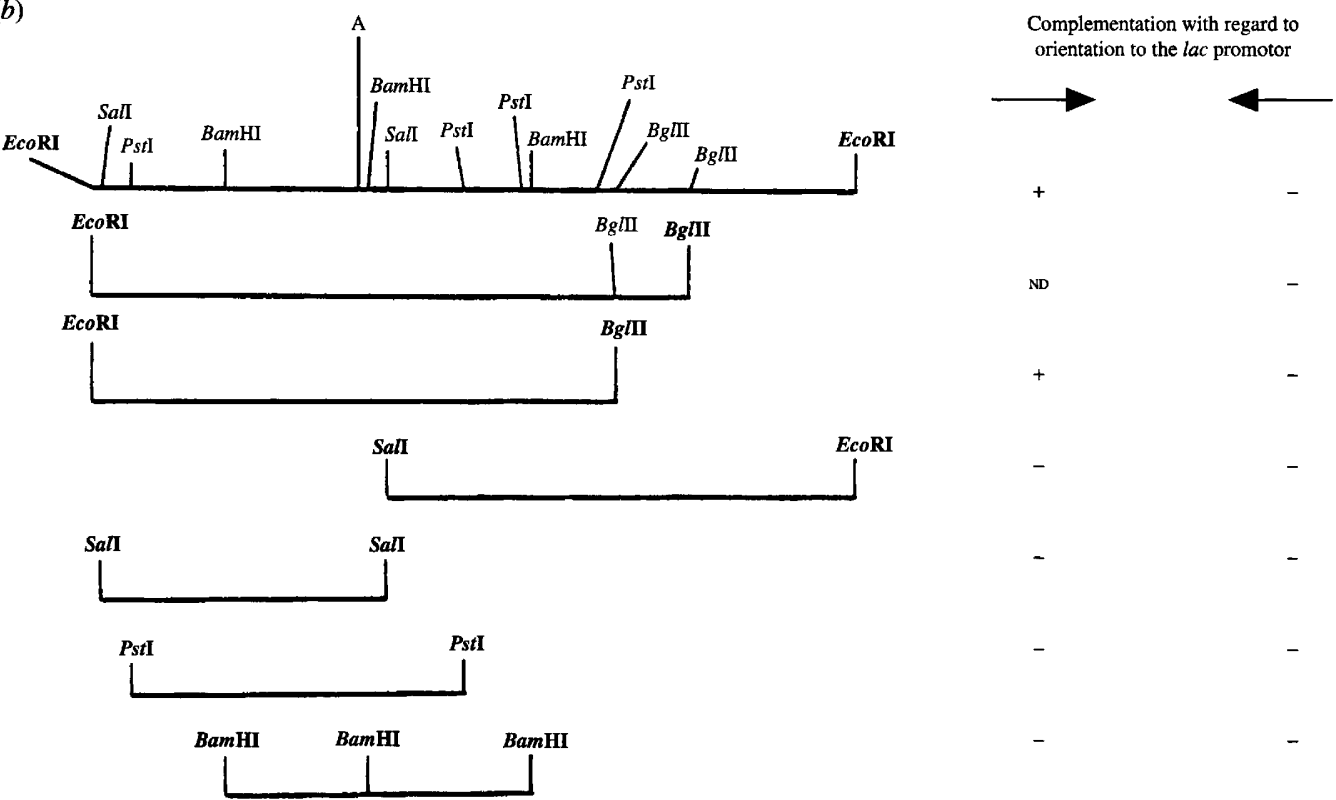

Fig. 2. Complementation of the transposon-induced mutation in $R$. sphaeroides M22 by a DNA fragment from $R$. sphaeroides Si4. (a) Restriction map of the $8 \mathrm{~kb} E c o \mathrm{RI}$ fragment from $R$. sphaeroides Si4 that complements the mutation. The fragment has been cloned into the vector pRK415. 'A' marks the position where the transposon is inserted in $R$. sphaeroides M22. This position was identified by comparison with the restriction map of plasmid pAK20, which contains the DNA flanking the transposon in M22. (b) Identification of subfragments of the $E c o$ RI fragment that complement the mutation. 'A' marks the position where the transposon is inserted. $\rightarrow$ indicates that the orientation of the fragment in pRK415 is the same as that of the tet, lac promotor; $\leftarrow$ indicates the opposite orientation. +, Fragment complements the mutation; -, fragment does not complement; ND, not determined.

In order to clone DNA flanking the site of transposon insertion, genomic DNA from $R$. sphaeroides M22 was isolated and digested with EcoRI. An EcoRI digest produced a fragment that contained the kanamycin resistance gene of the transposon as well as flanking DNA. Using the kanamycin resistance gene of $\operatorname{Tn} 5$ as a probe the size of this fragment was determined by Southern hybridization to be approximately $9.5 \mathrm{~kb}$. Because the portion of the fragment contributed by $\operatorname{Tn} 5$ is about $6.5 \mathrm{~kb}$ in size, the EcoRI fragment contained about $3 \mathrm{~kb}$ of Rhodobacter DNA. $R$. sphaeroides M22
DNA digested with EcoRI was separated following electrophoresis in agarose, and DNA of about $9.5 \mathrm{~kb}$ in size was isolated from the gel and cloned into pUC19. The desired plasmid (pAK10) containing portions of $\mathrm{Tn} 5$ and the flanking DNA of M22 was obtained. In order to remove most of the DNA sequences derived from Tn5 a $3.9 \mathrm{~kb} E c o$ RI/HindIII fragment was subcloned into pUC19. This plasmid was designated pAK20 and contains predominantly $R$. sphaeroides DNA.

The $E c o$ RI/HindIII fragment of pAK20 was used as a probe for cloning of $m t l K$. Genomic DNA of $R$. 

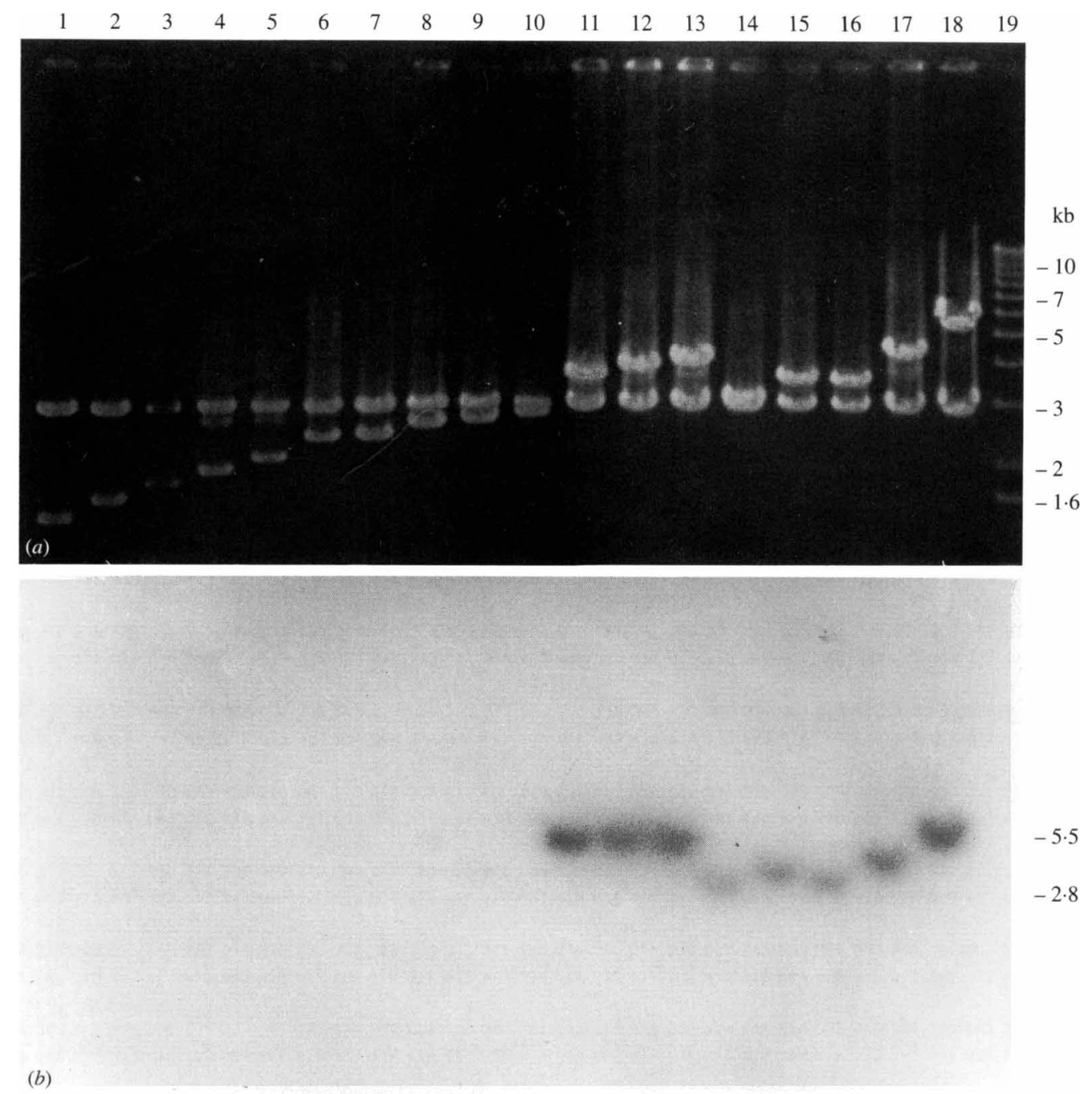

Fig. 3. Identification of those plasmids still containing the $\mathrm{N}$-terminal portion of the $m t l K$ gene among plasmids subcloned from pAK60 with deletions of different size which originated from the $E c o$ RI site of the EcoRI/BgIII fragment. (a) Ethidium-bromide-stained agarose gel. Lanes 1-18, plasmids with deletions of different size, digested with EcoRI/HindIII; lane 19, size marker (1 kb ladder). (b) Autoradiogram of a Southern hybridization of a blot from the gel shown in (a) with oligonucleotide 1 (Fig. $1 b$ ) as probe.

sphaeroides $\mathrm{Si} 4$ was digested with EcoRI and separated in an agarose gel. Southern hybridization with this probe resulted in a single signal approximately $8 \mathrm{~kb}$ in size. EcoRI-digested DNA from Si4 of about $8 \mathrm{~kb}$ was isolated from an agarose gel, ligated into pRK415, and the resulting construct was transferred into $E$. coli JE85. Plasmids were isolated from the transformants and Southern hybridizations were performed with the EcoRI/ HindIII fragment of pAK20 as probe. We subsequently identified a plasmid that contained an $8 \mathrm{~kb}$ DNA fragment which hybridized with the probe and was designated pAK30. Following transfer of pAK30 to $R$. sphaeroides $\mathrm{M} 22$ by triparental mating the transconjugant strain was able to grow on D-mannitol. Measurements of polyol dehydrogenase activity in crude extract proved that MDH activity was restored (Table
2), indicating that the cloned EcoRI fragment was able to complement the transposon-induced mutation in $R$. sphaeroides M22.

\section{Analysis of the complementing DNA fragment}

A restriction map of the $8 \mathrm{~kb}$ fragment that complements the mutation in R. sphaeroides M22 is shown in Fig. 2(a). Subfragments were cloned into pRK415 and the resulting plasmids were introduced into $R$. sphaeroides M22 by triparental mating. Growth on D-mannitol and $\mathrm{MDH}$ activity in crude extracts of the resulting strains was measured. During these investigations it became apparent that only one of two possible orientations of the cloned DNA fragment in plasmid pRK415 was essential for complementation. Most likely a promotor residing 


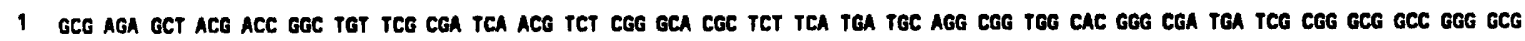

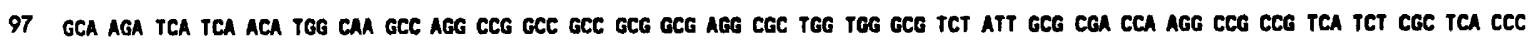

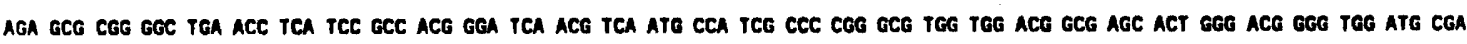

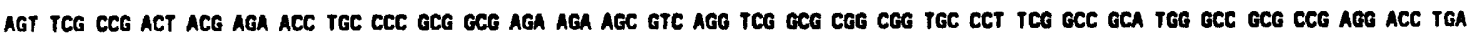

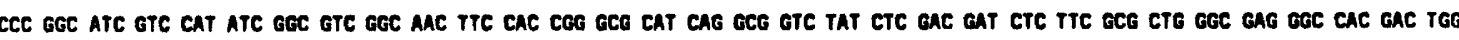
Pro Gly ile Val his tle Gly Vel Gly Asn Phe His Arg Ala His Gin Alo Val Tyr Leu Asp Asp Leu Phe Ala Leu Gly Glu Gly His Asp Trp

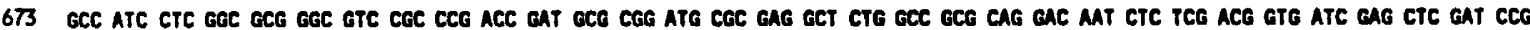
Ala Ile Leu Gly Alo Gly val Arg Pro thr Asp Ala Arg Met Arg Glu Alo Leu Ala Ale Gln Asp Asn Leu ser thr Val Ile olu Leu Asp Pro

769 GCG GGC CAC CEG GCC CEG CAG GTG GEG GCE ATG GTO GGC TTC CTG CCG GTC GAG GCC GAC MAT GCG GCC CTE ATC GAG GCC ATG TCG GAT CCE COC Ala Gly his Arg Ala Arg Gin Val Gly Ala Met Val gly Phe Leu Pro val olu Alo Asp Asn Ala Ala Leu Ile Glu Ala Met Ser Asp Pro Arg

865 ATC CGC ATC GTC TCG CTE ACC GTG ACC GAG GGC GEC TAT TAT GTC GAT GCC TCG GEC GCC TTC GAT CCE ACE CAT CCC GAT ATC GTG GCC GAT GCG

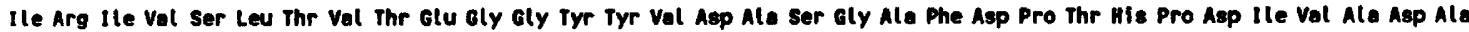

961 GCC CAT CCT GCE CGG CCC GCG ACC GCC TTC GEC GCG ATC CTC GCC GCC CTC CEC GCC CEC CEC GAC GCE GEG GTT ACA CCC TTC ACC GTG ATG TCC

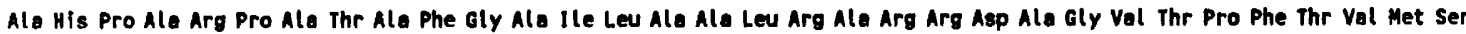

1066 TGC GAC AAC CTC CCC GGC AAC GGC CAT GTC ACC CEC AAC GCC GTE GTE GEC CTG GCC GAO CTC TAC GAC GCC GAG CTT GCG GGC TGG GTG AAG GCG Cys Asp Asn Leu Pro Gly Asn Gly His Val Thr Arg Asn Ala Val Val Gly Leu Ala Glu Leu Tyr Asp Ala gtu Leu Ala Gly Trp Val Lys Ala

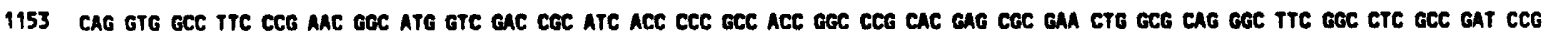
Gin Val Ala phe Pro Asn Gly Met val Asp Are Ile thr Pro Ale Thr Gly Pro His Glu Arg Glu Leu Ala Gln Gly Phe Gly Leu Ala Asp Pro

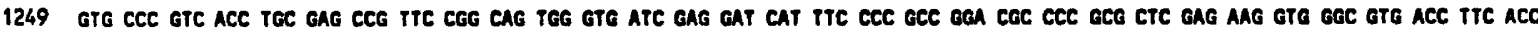
val pro val thr Cys Glu Pro phe Arg Gin trp Val lle Glu Asp His Phe Pro Ale Gly Arg Pro Ala Leu glu Lye val Gly Val Thr Phe Thr

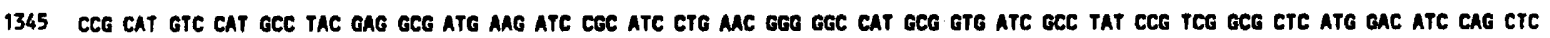
Pro his val His Alo tyr Glu Alo Met Lys lle Arg Ile Leu Asn Gly Gly His Alo Val Ile Alo Tyr Pro ser Alo Leu Met Asp Ile Gln Leu

1441 GTG CAC GCG GCC ATG GCC CAT CCE CTG ATC GCE GCC TTC CTE CAC AAG GTC GAG GTC GAG GAG ATC CTG CCC CAT GTC CCE CCC GTG CCC GAC ACC Val His Ala Ala Het Ala His Pro leu lle Ala Ala phe Leu His Lys Val glu Val glu glu lle Leu Pro his Val Pro Pro Val Pro Asp thr

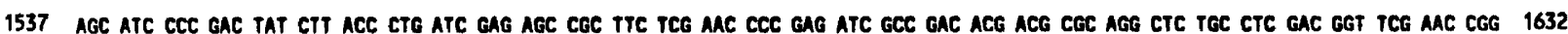
Ser Ile Pro Asp Tyr Leu Thr Leu Ile Glu Ser Arg Phe Ser Asn Pro Glu lle Ala Asp Thr Thr Arg Arg Leu Cys Leu Asp Gly Ser Asn Arg

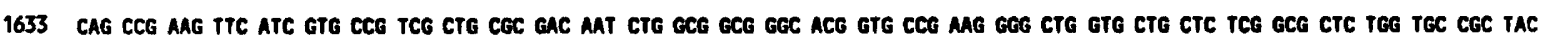
Gin Pro Lys phe Ile val pro ser Leu Arg Asp Asn Leu Ale Ala Gly Thr Val Pro Lys Gly Leu Val Leu Leu Ser Alo Leu Trp Cys Arg Tyr

1729 TGC TTC GGC ACG ACE GAC TCE GGC GTT GTG GTC GAG CCG AAC GAT CCG AAC TGG ACE GCE CTE CAG GAC CGG GCG CGG CGG GCG MAG GAG ACG CCG 1824 Cys Phe Gly Thr Thr Asp Ser Gly Vat Val Vol Gtu Pro Asn Asp Pro Asn Trp Thr Ala Leu Gln Asp Arg Ala Arg Arg Ala Lys Glu Thr Pro

1825 GCC GAG TGE CTE GCE ATG ACC GAA GTC TAC GGC GAT CTE GCE CAG AAC GAT CTT CTE GCB GCC GAG TTC GCG GCA GCC CTC GAG GCG GTC TGE CGC 1920 Ala Glu Trp leu Ala Met thr Glu val tyr Gly Asp Leu Ala Gln Asn Asp Leu Leu Ala Ala glu Phe Ala Alo Ala Leu glu Alo val trp Arg

1921 GAC GGG GCC GAG GCG GTE CTE CEG CGC TTC CTC GCE GCC TGA TCC GCA EGG CCC AGC CGC TCG GAG CAC CEA AGC GGA GCC CCT GCC CCT TGC GEC 2016 Asp Gly Ala Glu Ala Val Leu Arg Arg Phe Leu Ala Ala...

2017 GCA CCG TGA GGC GAA ACG ACC GGG CCA CCC CGG GEC CAC CGC CTC GGT AAC ACC ATG GTA TCG CGC AAG AAT GCC GGC GCC TCT GCC GAA CGG GCC 2112

2113 CGG CTG CCG GGC GAG GEG CCG GAC TTG TCA AGG CGE CGG CCC TCG GGT AGA GAG GGC GGG CGT GGC CCC GTT AGC ACA GTG GTA GTG CAG CGC TCT 2208

2209 tgt aAA GCG Aag GTC GTt CGT tCA aAt CGg ACA CGG GGC ATC GCG ATC CTC CCT CCG ACT TCG

Fig. 4. Nucleotide sequence of the MDH gene $(m t l K)$ with flanking regions and derived amino acid sequence for the enzyme. The Shine-Dalgarno sequence is underlined. 'Transposon' marks the position were $\operatorname{Tn} 5$ is inserted in $R$. sphaeroides M22. 


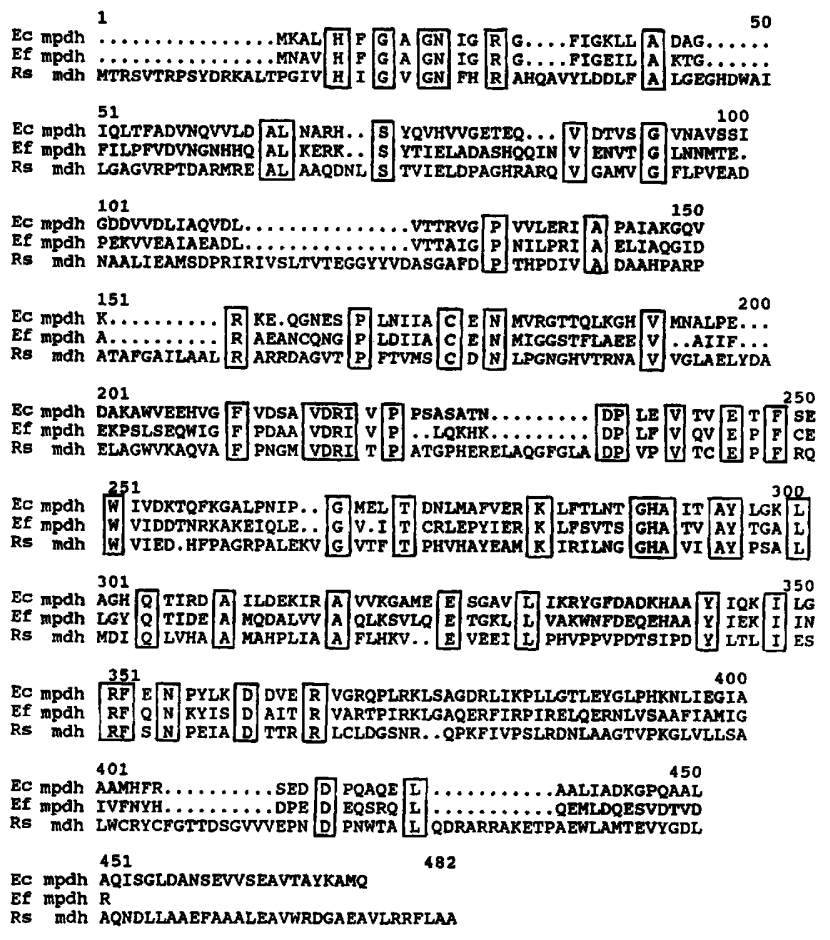

Fig. 5. Alignment of the amino acid sequence of MDH from $R$. sphaeroides $\mathrm{Si} 4$ (Rs $\mathrm{mdh}$ ) and the mannitol-1-phosphate dehydrogenases from E. coli (Ec mpdh) and Enterococcus faecalis (Ef $\mathrm{mpdh}$ ). Identical amino acids in all three enzymes are framed.

on the vector was necessary for complementation. Cloned in the correct orientation into pRK 415 , a $5.5 \mathrm{~kb}$ $E c o \mathrm{RI} / B g I \mathrm{II}$ subfragment was the smallest DNA fragment sufficient for complementation. All smaller fragments investigated did not complement the mutation (Fig. 2b).

In order to verify that a promotor present on the vector was required for complementation of the EcoRI/ $B g l I$ fragment, the transcription/translation stop cartridge omega spectinomycin ${ }^{\mathrm{r}} / \mathrm{streptomycin}^{\mathrm{r}} \quad\left(\mathrm{Spec}^{\mathrm{T}} /\right.$ Strep $^{\mathrm{r}}$ cartridge) (Prentki \& Krisch, 1984) was inserted at either end of the fragment. For this purpose the $E c o$ RI/Bg/II fragment was cloned into the SmaI site of the multiple-cloning site from pRK415 and the Spec ${ }^{\mathrm{r}}$ / Strep $^{r}$ cartridge was cloned in one case into the HindIII site and in the other case into the EcoRI site of this plasmid. The resulting plasmids were introduced into $R$. sphaeroides M22 by triparental mating. When the $\mathrm{Spec}^{\mathrm{r}} / \mathrm{Strep}^{\mathrm{r}}$ cartridge was inserted into the EcoRI site, this plasmid could still complement the mutation in M22. However, when the $\operatorname{Spec}^{r} / \operatorname{Strep}^{r}$ cartridge was cloned into the HindIII site, which means that it was located between the $E c o \mathrm{RI} / B g I \mathrm{II}$ fragment and the lac, tet promotors of the vector, there was no complementation of the mutation in M22. These results proved that a promotor located on the vector was required for complementation by the cloned DNA fragment. In addition, by having determined the orientation of the gene(s) necessary for complementation we were able to determine the direction of transcription and the orientation of the desired coding sequence.

In order to ascertain that the complementing $5.5 \mathrm{~kb}$ $E c o$ RI/ $B g I I I$ fragment contained the structural gene for mannitol dehydrogenase, Southern hybridizations were performed using the four oligonucleotides shown in Fig. $1(b)$ as probes. Hybridization signals were obtained with all four oligonucleotide probes, indicating that the cloned DNA fragment contained the $m t l K$ structural gene.

\section{Sequencing of $\mathrm{mtlK}$}

For sequencing of the mannitol dehydrogenase gene the complementing $E c o \mathrm{RI} / B g I I \mathrm{I}$ fragment was cloned in both orientations into pBluescript II KS. After nested deletions had been produced, Southern hybridizations were performed with the plasmids obtained, which contained inserts of decreasing length, using oligonucleotide 1 (Fig. 1 ) as probe (Fig. 3). In this way it was possible to identify the smallest fragment that still hybridized to the probe, indicating that it contained the amino-terminal sequence of $m t l K$. Both strands of the DNA in this region were sequenced, using both manual sequencing methods and automated sequencing with dye primers. To close gaps in the derived sequence, synthetic oligonucleotides were used as primers. The resulting DNA sequence is shown in Fig. 4. The sequence contains an open reading frame starting at nucleotide 529 which encodes the identical amino acid sequence as determined by $\mathrm{N}$-terminal analysis of the isolated $\mathrm{MDH}$ (Fig. 1a), with the initiator methionine removed from the mature protein. This proves definitively that this open reading frame encodes the structural gene for $\mathrm{MDH}$. The size of the protein encoded by this gene is 476 amino acids; its molecular mass is $51404 \mathrm{Da}$. This is consistent with the molecular mass of isolated $\mathrm{MDH}$, which was determined to be about $50000 \mathrm{Da}$ (Schneider \& Giffhorn, 1989). The ATG start codon of $m t l K$ is preceded by the Shine-Dalgarno-like sequence (Shine \& Dalgarno, 1974) GAGGT. A promotor-like region was not found in the sequenced upstream region, which is consistent with the finding that a promotor of the vector was necessary for complementation by the cloned fragment.

Screening of the proteins in the data banks GenBank Release 72.0 (6-92), EMBL Release 31.0 (6-92), and SwissProt Release 22.0 (6-92) with the amino acid sequence of $\mathrm{MDH}$, utilizing the University of Wisconsin Genetics Computer Group software program, identified two proteins with a low degree of similarity to $\mathrm{MDH}$ : the mannitol-1-phosphate dehydrogenases of $E$. coli (Davis et al., 1988; Jaiang et al., 1991) and Enterococcus faecalis (Fischer et al., 1991), with identity values to MDH of 
$28 \cdot 1 \%$ and $26 \cdot 3 \%$, respectively. An alignment of the amino acid sequences is shown in Fig. 5.

\section{Identification of the position of insertion of Tn5 in $R$. sphaeroides M22}

The restriction map of plasmid pAK20, which contains a portion of $\operatorname{Tn} 5$ and flanking DNA from $R$. sphaeroides M22, showed that the flanking DNA possesses an SstI site close to the position of insertion of $\operatorname{Tn} 5$. In order to sequence the region near the position of insertion of the transposon, the SstI/HindIII fragment from pAK20 was cloned into M13mp19. After transformation of $E$. coli JM101, single-stranded DNA was isolated and used as template for sequencing. A comparison of this sequence with the sequence of $m t l K$ proved that the DNA flanking the transposon is part of the $m t l K$ gene. Therefore it was possible to identify the exact position where the transposon was inserted in mutant $R$. sphaeroides M22: after nucleotide 848 of the sequence shown in Fig. 4.

\section{Discussion}

For growth on D-mannitol, D-glucitol or D-arabitol $R$. sphaeroides $\mathrm{Si} 4$ produces a polyol dehydrogenase which oxidizes all three of the polyols (Schneider \& Giffhorn, 1989). The enzyme has been designated mannitol dehydrogenase (MDH) because of its high affinity to Dmannitol. It can be utilized for a quantitative determination of D-mannitol (Schneider \& Giffhorn, 1989). Because of its monomeric structure it is particularly suitable for studies aimed at altering the specificity of polyol dehydrogenases. The transposon-induced mutant of $R$. sphaeroides $\mathrm{Si} 4$ exhibited no detectable $\mathrm{MDH}$ or arabitol dehydrogenase activity. However, the specific sorbitol dehydrogenase activity in crude extracts was about the same in the wild-type and mutant M22 (Table 2). The source of the sorbitol dehydrogenase activity in M22 is unknown. To date only two polyol dehydrogenases of $R$. sphaeroides Si4 are known, MDH and a ribitol dehydrogenase (Kahle et al., 1992; Schneider \& Giffhorn, 1989). During growth on D-mannitol, ribitol dehydrogenase is repressed and only a low basal level of activity is detectable. This is also true in the mutant strain M22 (Table 2). Obviously the sorbitol dehydrogenase activity belongs to a third, so far undiscovered, enzyme. This assumption is further supported by the pattern of polyol dehydrogenase activities in strain M22 complemented with pAK30 (Table 2). This strain contains a very high specific sorbitol dehydrogenase activity which is clearly higher than the activity observed with D-arabitol, while the isolated MDH possesses, under saturating conditions, a higher activity with Darabitol than with D-glucitol (sorbitol) (Schneider \&
Giffhorn, 1989). Most likely the sorbitol dehydrogenase activity in M22(pAK30) is the sum of the activities derived from $\mathrm{MDH}$ and from the newly discovered sorbitol dehydrogenase.

Using DNA flanking the transposon in M22 as probe, a $5.5 \mathrm{~kb}$ DNA fragment from $R$. sphaeroides $\mathrm{Si} 4$ has been cloned that is capable of complementing the mutation in M22. For successful complementation a promotor present on the vector was required. The cloned fragment contains the structural gene for $\mathrm{MDH}$ as well as $1.9 \mathrm{~kb}$ of DNA upstream of $m t l K$. The requirement of a vector promotor for $m t l K$ expression indicates that the actual promotor for $m t l K$ is not located on the cloned fragment but even further upstream. In addition, DNA fragments smaller than $5.5 \mathrm{~kb}$ were not sufficient for complementation, although the BamHI fragment tested (Fig. $2 b$ ) contained the complete MDH gene. This result suggests that there is at least one additional gene downstream of $m t l K$ that is also required for complementation. Otherwise the BamHI fragment which contained the complete MDH gene should have complemented the mutation in $R$. sphaeroides M22 when cloned in the right orientation into the vector pRK415. Obviously $m t l K$ is part of a larger operon.

The $m t l K$ structural gene encodes a protein of 476 amino acids (without the initiator-methionine) with a molecular mass of $51400 \mathrm{Da}$. Screening of the data banks against the amino acid sequence of $\mathrm{MDH}$ identified only the mannitol-1-phosphate dehydrogenases of E. coli (Davis et al., 1988; Jaiang et al., 1991) and Enterococcus faecalis (Fischer et al., 1991) with similarity to $\mathrm{MDH}$. This result was not surprising, because the MDH of $R$. sphaeroides is the first bacterial MDH that has been sequenced. Among bacterial polyol dehydrogenases, only the sequence of the ribitol dehydrogenase from Klebsiella pneumoniae has been determined (Loviny et al., 1985). Similarities to this enzyme have not been found. The mannitol-1-phosphate dehydrogenases from E. coli and Ent. faecalis possess an amino acid identity over the entire protein of $40 \%$ (Fischer et al., 1991). The similarity to MDH from $R$. sphaeroides, which does not convert phosphorylated polyols, is more distant, with an identity of $28.1 \%$ to the $E$. coli enzyme and $26.3 \%$ to the Ent. faecalis enzyme. The alignment of the three proteins (Fig. 5) reveals that the homology between them is not equally distributed over the complete sequence. The first 210 amino acids exhibit very few similarities with the exception of a short region near the $\mathrm{N}$-terminus of the proteins which is the putative NAD-binding site (see below). In the region from amino acid 211 to 363, thirty-three amino acids are identical between all three proteins. In addition only a few minor gaps are required to obtain the alignment. The identity between all three proteins in this region is $22 \%$. 
This indicates that this portion of the protein may be involved in binding of the substrate (D-mannitol or mannitol 1-phosphate).

As the result of sequence comparisons several different families of dehydrogenases have been found. The beststudied families are the short-chain dehydrogenases (Neidle et al., 1992; Persson et al., 1991b) and the medium-chain family (Jörnvall et al., 1987). In addition a long-chain family (Persson et al., 1991 a) and a family of iron-activated alcohol dehydrogenases (Neale et al., 1983; Scopes, 1983) are known. Common to all NADbinding dehydrogenases is a short segment, the NADbinding site. Several studies have demonstrated that the NAD-binding sites contain three strictly conserved glycine residues (Jörnvall et al., 1987; Persson et al., $1991 b$; Wierenga et al., 1985). With respect to the spacing of the glycine residues two different classes exist. The medium-chain dehydrogenases, and many other dehydrogenases (Wierenga et al., 1985), possess a Gly-XGly-X-X-Gly-pattern in the NAD-binding domain. Members of the short-chain dehydrogenase family have a different spacing, Gly-X-X-X-Gly-X-Gly (Neidle et al., 1992; Persson et al., 1991b). In the MDH from $R$. sphaeroides, starting with amino acid 18 the sequence is Gly-Ile-Val-His-Ile-Gly-Val-Gly, which is similar to the pattern found for members of the short-chain family, although four residues instead of three are located between the first and the second glycine residue. In case of the alcohol dehydrogenase from Drosophila melanogaster only two amino acids are located between the two glycine residues (Persson et al., 1991 b), indicating that small differences in the spacing may be possible. Therefore the segment starting at amino acid 18 is the best candidate for the NAD-binding region of $\mathrm{MDH}$ from $R$. sphaeroides Si4.

The MDH of $R$. sphaeroides does not belong to either of the two well-studied dehydrogenase families, short- or medium-chain. The dehydrogenases that belong to the short-chain family are about 250 amino acids in size and possess several conserved residues (Persson et al., 1991 b). Although the NAD-binding domain of the R. sphaeroides MDH is of the same type as in these dehydrogenases, the MDH differs completely with regard to length and all other conserved residues. The enzymes of the mediumchain family, with about 350 residues, are smaller than MDH from $R$. sphaeroides and the arrangement of the domains is different. In the medium-chain dehydrogenases the substrate-binding region of the protein is closer to the N-terminus than the NAD-binding domain (Jörnvall et al., 1987), while the opposite arrangement is found in MDH. In addition, no sequence similarities were found between MDH and medium-chain dehydrogenases. The group of long-chain dehydrogenases comprises enzymes with $450-600$ amino acid residues. The enzymes in this family are more heterogeneous than the members of the other dehydrogenase families. No entirechain homologies have been detected, only similarities in single segments (Persson et al., 1991a). One segment of similarity is the NAD-binding domain. Because MDH from $R$. sphaeroides is also a dehydrogenase with more than 450 amino acid residues, and with no similarities to dehydrogenases of the other families, it can be considered as another member of the heterologous group of longchain dehydrogenases.

We thank Dr B. Schmidt, Biochemie II, Universität Göttingen, Germany, for determining the $\mathrm{N}$-terminal amino acid sequence of $\mathrm{MDH}$, Greg Shipley for performing the automated sequencing as well as the synthesis of the oligonucleotides. We gratefully acknowledge Mark Moore for developing the method for enrichment of nongrowing mutants of $R$. sphaeroides. We acknowledge the support of numerous colleagues in the laboratory, in particular of Antonius Suwanto and Ellen Neidle.

This work was supported by a grant of the Deutsche Forschungsgemeinschaft to K.-H.S. and by grants GM15590 and GM31667 to S.K.

\section{References}

Berezenko, S. \& STURGeON, R. J. (1991). The enzymatic determination of D-mannitol with mannitol dehydrogenase from Agaricus bisporus. Carbohydrate Research 216, 505-509.

BIRNBoIM, C. \& Doly, J. (1979). A rapid alkaline extraction procedure for screening recombinant plasmid DNA. Nucleic Acids Research 7, 1513-1523.

BOyeR, H. W. \& Roulland-Dussoix, D. (1969). A complementation analysis of the restriction and modification of DNA in Escherichia coli. Journal of Molecular Biology 41, 459-472.

Davis, T., Yamada, M., Elgort, M. \& SAiER, M. H., JR (1988). Nucleotide sequence of the mannitol $(\mathrm{mtl})$ operon in Eschericia coli. Molecular Microbiology 2, 405-412.

Ditta, G., Stanfield, S., Corbin, D. \& Helinski, D. R. (1980). Broad host range DNA cloning system for Gram negative bacteria: construction of a gene bank of Rhizobium meliloti. Proceedings of the National Academy of Sciences of the United States of America 77, 7347-7351.

Fischer, R., Pogge von Strandmann, R. \& Hengstenberg, W. (1991). Mannitol-specific phosphoenolpyruvate-dependent phosphotransferase system of Enterococcus faecalis: Molecular cloning and nucleotide sequences of the enzyme III $^{\mathrm{mtl}}$ gene and the mannitol-1phosphate dehydrogenase gene, expression in Escherichia coli, and comparison of the gene product with similar enzymes. Journal of Bacteriology 173, 3709-3715.

GOA, J. (1953). A micro Biuret method for protein determination. Scandinavian Journal of Clinical Investigations 5, 218-222.

HoRwITZ, S. B. \& KaPLAN, N. O. (1964). Hexitol dehydrogenases of Bacillus subtilis. Journal of Biological Chemistry 239, 830-838.

Hynes, M. F., Quandt, J., O'ConNel, M. P. \& PÜHLeR, A. (1989). Direct selection for curing and deletion of Rhizobium plasmids using transposons carrying the Bacillus subtilis $s a c B$ gene. Gene 78, 111-120.

Jaiang, W., Wu, L. F., Tomich, J., SaIER, M. H., JR \& NichHaus, W. G. (1991). Swissprot Data Bank (accession no. X51359).

Jörnvall, H., Persson, B. \& JefFery, J. (1987). Characteristics of alcohol/polyol dehydrogenases. European Journal of Biochemistry 167, 195-201.

KAHLe, C., SChNeIder, K. H. \& Giffhorn, F. (1992). Pentitol metabolism of Rhodobacter sphaeroides Si4: purification and characterization of a ribitol dehydrogenase. Journal of General Microbiology 138, 1277-1281.

KeEn, N. T., Tamaki, S., Kobayashi, D. \& Trollinger, D. (1988). 
Improved broad host-range plasmids for DNA cloning in Gramnegative bacteria. Gene 70, 191-197.

Kiba, N., Inoue, Y. \& Furusawa, M. (1991). Flow-injection system for the fluorimetric determination of fructose with an immobilized mannitol dehydrogenase reactor. Analytica Chimica Acta 243, 183-186.

Loviny, T., Norton, P. M. \& Hartley, B. S. (1985). Ribitol dehydrogenase of Klebsiella aerogenes. Sequence of the structural gene. Biochemical Journal 230, 579-585.

Lueking, D. R., Fraley, R. T. \& Kaplan, S. (1978). Intracytoplasmatic membrane synthesis in synchronous cell populations of Rhodopseudomonas sphaeroides. Journal of Biological Chemistry 253, 451-457.

LunN, P. G., Northrop, C. A. \& Northrop, A. J. (1989). Automated enzymatic assays for the determination of intestinal permeability probes in urine. 2. Mannitol. Clinica Chimica Acta 183, 163-170.

MARMUR, J. (1961). A procedure for the isolation of deoxyribonucleic acids from microorganisms. Journal of Molecular Biology 3, 208-218.

Martinez, G., Barker, H. A. \& Horecker, B. L. (1963). A specific mannitol dehydrogenase from Lactobacillus brevis. Journal of Biological Chemistry 238, 1598-1603.

MOORE, M. D. \& KAPLAN, S. (1992). Identification of intrinsic highlevel resistance to rare-earth oxides and oxyanions in members of the class Proteobacteria: Characterization of tellurite, selenite, and rhodium sesquioxide reduction in Rhodobacter sphaeroides. Journal of Bacteriology 174, 1505-1514.

Neale, A. D., Scopes, R. K., Kelly, J. M. \& Wettenhall, R. E. H. (1983). The two alcohol dehydrogenases of Zymomonas mobilis. European Journal of Biochemistry 154, 119-124.

Neidle, E., Hartnett, C., Orniston, N., Bairoch, A., Rekik, M. \& HARAYAMA, S. (1992). Cis-diol dehydrogenases encoded by the TOL pWW0 plasmid $x y l L$ gene and the Actinetobacter calcoaceticus chromosomal benD gene are members of the short-chain alcohol dehydrogenase superfamily. European Journal of Biochemistry 204, 113-120.

Neuberger, M. S., Patterson, R. A. \& Hartley, B. S. (1979). Purification and properties of Klebsiella aerogenes D-arabitol dehydrogenase. Biochemical Journal 183, 31-42.

Persson, B., Jefrery, J. \& Jörnvall, H. (1991 a). Different segment similarities in long-chain dehydrogenases. Biochemical and Biophysical Research Communications 177, 218-223.

Persson, B., KroOK, M. \& JöRnVALl, H. (1991b). Characteristics of short-chain alcohol dehydrogenases and related enzymes. European Journal of Biochemistry 200, 537-543.

PRENTKI, P. \& KRISCH, H. M. (1984). In vitro insertional mutagenesis with a selectable DNA fragment. Gene 29, 303-313.

RoDE, H. \& GIFFHORN, F. (1983). Adaptation of Rhodopseudomonas sphaeroides to growth on $\mathrm{D}(-)$-tartrate and large-scale production of constitutive $\mathrm{D}(-)$-tartrate-dehydratase during growth on DLmalate. Applied and Environmental Microbiology 45, 716-719.

SAMbrooK, J., Fritsch, E. F. \& Maniatis, T. (1989). Molecular Cloning: a Laboratory Manual, 2nd ed. Cold Spring Harbor, NY: Cold Spring Harbor Laboratory Press.

Schmolke, M., Bornemann, A. \& Guder, W. G. (1990). Polyol determination along the rat nephron. Biological Chemistry HoppeSeyler 371, 909-916.

SCHNEIDER, K. H. \& GIFFHORN, F. (1989). Purification and properties of a polyol dehydrogenase from the phototrophic bacterium Rhodobacter sphaeroides. European Journal of Biochemistry 184, $15-19$.

SCHNEIDER, K. H. \& GifFHoRN, F. (1991). Sorbitol dehydrogenase from Pseudomonas sp.: Purification, characterization and application to quantitative determination of sorbitol. Enzyme and Microbial Technology 13, 332-337.

SCOPES, R. K. (1983). An iron-activated alcohol dehydrogenase. FEBS Letters 156, 303-306.

SHINE, J. \& Dalgarno, L. (1974). The 3'-terminal sequence of Escherichia coli 16s ribosomal RNA: complementary to nonsense triplets and ribosome binding sites. Proceedings of the National Academy of Science of the United States of America 71, 1342-1346.

Simon, R., Priefer, U. \& PüHLER, A. (1983). A broad host range mobilization system for in vivo genetic engineering: transposon mutagenesis in Gram negative bacteria. Bio/Technology 1, 784-791.

SuWANTO, A. \& KaPlaN, S. (1992). A self-transmissable, narrow-hostrange endogenous plasmid of Rhodobacter sphaeroides 2.4.1: Physical structure, incompatibility determinants, origin of replication, and transfer functions. Journal of Bacteriology 174, 1124-1134.

TAYlor, S. S., RigBY, P. W. \& HaRTLEY, B. S. (1974). Ribitol dehydrogenase from Klebsiella aerogenes. Purification and subunit structure. Biochemical Journal 141, 693-700.

Wierenga, R. K., DeMaeyer, M. C. H. \& Hol, W. G. J. (1985). Interaction of pyrophosphate moieties with $\alpha$-helices in dinucleotide binding proteins. Biochemistry 24, 1346-1357.

YanisCh-PerRon, C., VieIRA, J. \& MrSSING, J. (1985). Improved M13 phage cloning vectors and host strains: nucleotide sequences of the M13mp18 and pUC19 vectors. Gene 33, 103-119. 